The International Journal of Banking and Finance, Volume 8 (Number 3) 2011: pages 54-72

\title{
FINANCIAL INTERMEDIARIES AND ECONOMIC DEVELOPMENT: EVIDENCE ON TRANSACTION COSTS OF BORROWING BY THE POOR
}

\author{
Vighneswara Swamy and B.K. Tulasimala \\ Indian Business School-Hyderabad and University of Mysore, India
}

\begin{abstract}
This study, while validating the increasing role for financial intermediaries in economic development, analyzes the importance of reducing the transaction costs for financial deepening and, consequently, economic growth. It shows that higher borrowing transaction costs for the poor in particular will retard the long-term growth of rural financial markets. Further, the empirical analysis based on our primary (survey) data indicates that the microfinance models of lending offer considerably lower costs of borrowing than those in regular models of direct lending by banks. The study suggests that microfinance model of lending can provide cost-efficient avenue for speedy financial development and, subsequently, economic growth.
\end{abstract}

Keywords: Transaction costs; Banks; Microfinance; Nonprofit institutions; NGOs; Economic development; Financial markets, Savings institutions, growth

JEL Classification: D23, G21, L31, O16, O43

\section{Introduction}

For a rationalist, a cleric is an unwanted intermediary in the path towards the divine. He finds the cleric as superfluous and prefers to remove him in a move towards perfect state of disintermediation where the people can directly deal with the divine. However, on the contrary, a rationalist would choose to accept an intermediary towards the achievement of economic growth in any economy. Financial intermediation wields positive influences on financial development as efficient finance contributes to economic development. The intermediation theory has endeavoured to explain why these financial intermediaries exist. Savings/investment process in a capitalist economy is structured around financial intermediation, thus making the financial intermediaries as cardinal to economic development. 
Conventional intermediation theories are based on the concepts of transaction costs and asymmetric information. These are constructed to suggest reason for the existence of financial institutions, which take deposits or issue insurance policies and channel the funds to the needy enterprises, apart from serving to reduce transaction costs and informational asymmetries in an economy. On the other hand, in recent past there have been noteworthy vicissitudes, which deserve the attention of a researcher. Transaction costs and asymmetric information have declined, and intermediation has increased. As deregulation and deepening of financial markets tend to reduce transaction costs and informational asymmetries, the propositions of financial intermediation theory need a review and questioning. This diverges from the emerging point of view that financial intermediation is a value-creating economic process. The given paradox necessitates more justifications from the traditional theory of intermediation. Conventional theory is wanting in explaining the persisting and expanding economic importance of financial intermediaries.

In view of the enormous socio-economic importance of financial intermediaries particularly in rural finance in the context of a developing economy, this study points to an increasing role of financial intermediaries much beyond the traditional viewpoint of information asymmetries and transaction costs. Given these new evolving economic scenarios, this study intends to analyse and discuss the role of intermediation in the contemporary context. Obviously, this study argues that many current theories of intermediation, to a great extent, focus on the functions of institutions which are not that crucial in evolving financial systems and inadequate to provide an acceptable answer to the question as to why and how the real life financial intermediaries continue to exist. Empirical observations indicate at an increasing role for financial intermediaries in economies that experience vastly decreasing information and transaction costs. This paper goes into this paradox and comes up with a new dimension towards understanding the concept of financial intermediation.

This article is structured as follows. In section 2, the concept of financial intermediation and consequent financial development is critically examined with relevant literature wherein it is attempted to infer key predictions with regard to the role of financial intermediaries in modern economic development. However, since not all the developments in this field could be detailed due to various limitations, the focus is on the basic rationale for financial intermediaries i.e. transaction costs. In section 3, the concept of transaction costs and their economic significance in financial intermediation are analysed. We provide the details of objectives of the study, methodology, and research design including area of study, data collection methods employed in 
section 4. Empirical results are presented in section 5 while the limitations, policy choices, and conclusion are presented in section 6 .

\section{Financial Intermediation and Financial Development}

The finance-growth nexus is an established source of debate among economists. From the time when the seminal work of Patrick (1966), in which it was first hypothesized as a bi-directional relationship between financial development and economic growth, subsequent enormous empirical literature has developed testing this hypothesis (Levine, 1997). Financial intermediation can induce economic growth by influencing the saving rate as well as social marginal productivity of investment. Obviously, financial development will be positive for economic growth. Then, what is the role of financial intermediaries? The answer lies in the modest view of financial intermediation, which suggests that financial intermediaries serve to transfer financial resources from net savers in an economy to net investors. They play a key role in pooling the savings for economic growth. Further, it is observed, as the gross national savings of the economy increases, there is a positive impact on GDP of the economy (see Figure 1).

The movement of gross national savings (GNS) as against the GDP in the Organisation for Economic Co-operation and Development (OECD) countries in the period from 2000 to 2008 is presented in Figure 1. It is apparent from the figure that gross national savings has a direct relationship on the growth rates of GDP of the economies. The significance of financial intermediaries in the transmission of economic surpluses to the needy areas of investment in the economies is well illustrated for these selected countries.

As stated by the modern theory of financial intermediation, financial intermediaries are active because market imperfections prevent savers and investors from trading directly with each other in an optimal way. The most important market imperfections are the informational asymmetries concerning the savers and investors. Financial intermediaries (as agents and as delegated monitors) fill information gaps between ultimate savers and investors. This is because they have a comparative informational advantage over ultimate savers and investors. They watch over and scrutinise investors on behalf of savers. 


\section{Figure 1: Selected OECD gross national saving (GNS) as percentage to GDP and}

\section{GDP growth rate}

Figure 1-a

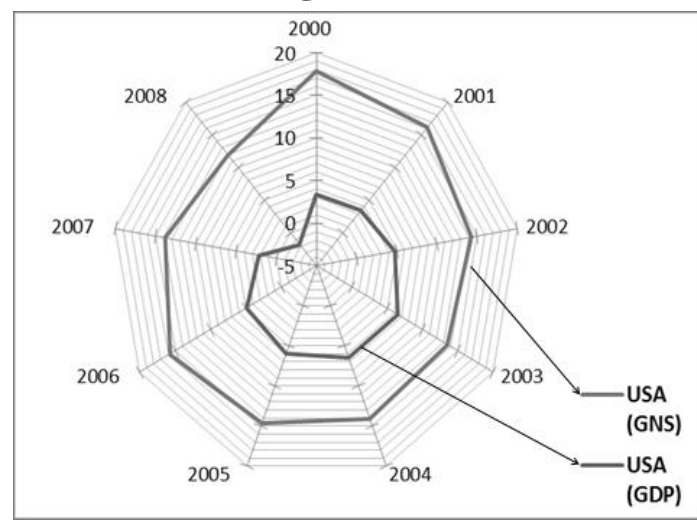

Figure 1-c

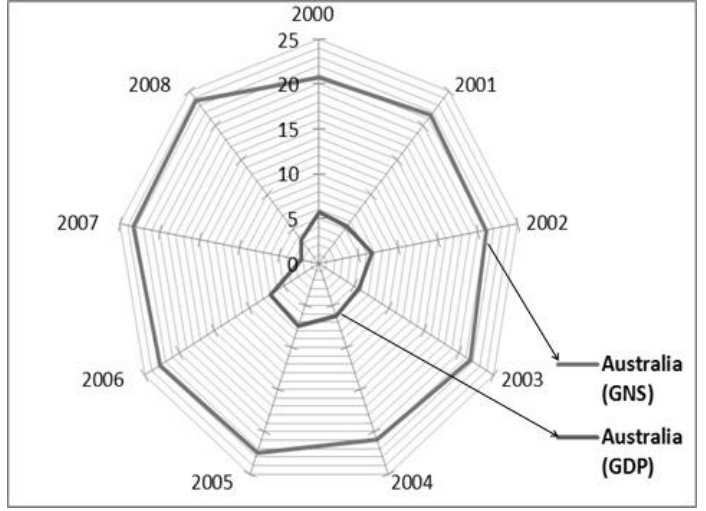

Figure 1-e

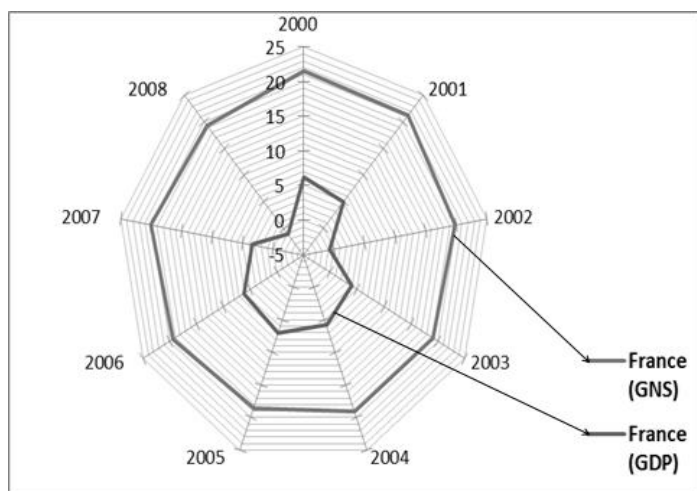

Figure 1-b

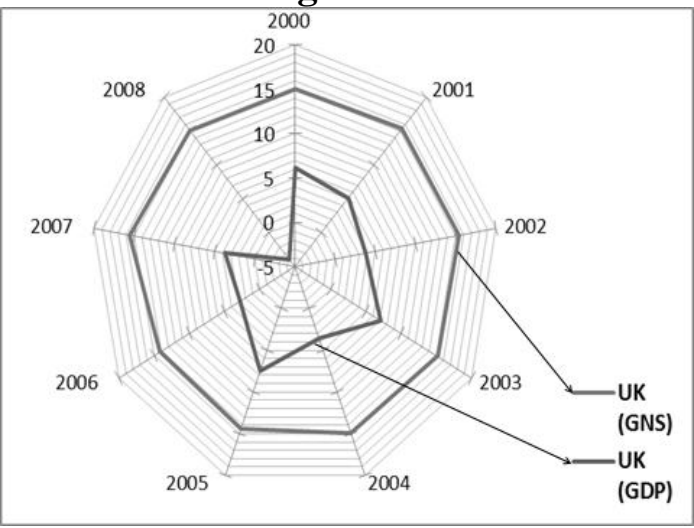

Figure 1-d

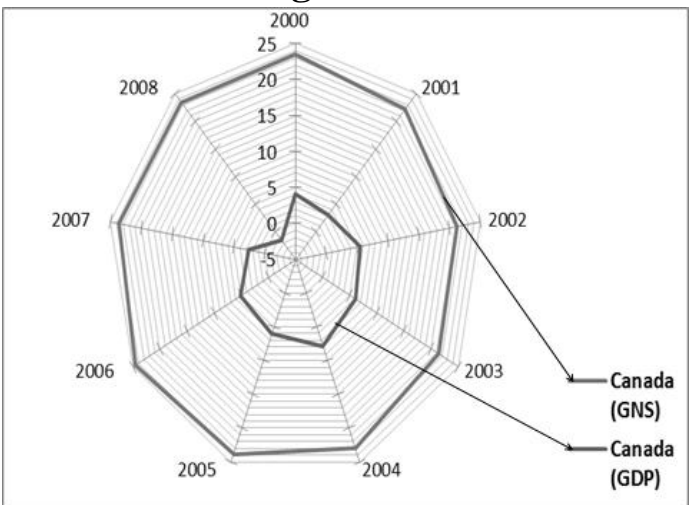

Figure 1-f

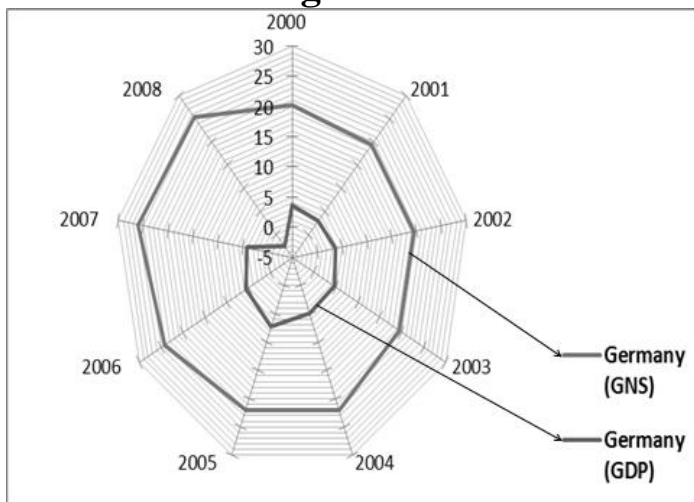

Figure 1-g

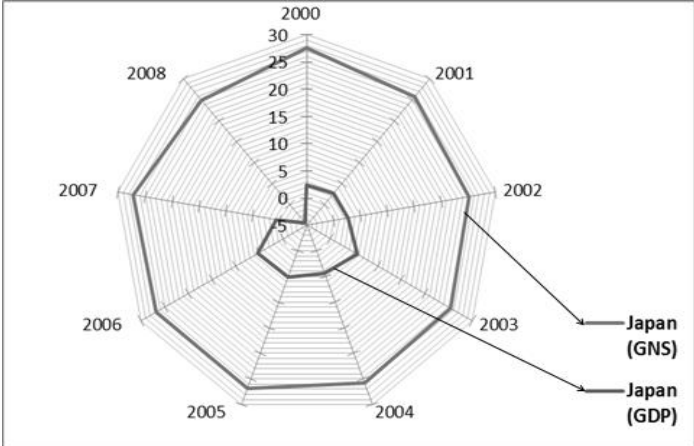

Source: All the above figures has been constructed for the study based on the data collected from the World Bank website. 
However, in essence we can make out three reasons for financial intermediaries: $(i)$ information problems, (ii) transaction costs and (iii) regulatory factors. Informational asymmetries problem is an ex ante and by engendering adverse selection, they can generate moral hazard. They can also be of an ex post nature resulting in auditing or expensive verification and enforcement by the state. As a result, these information asymmetries by generating market imperfections as in the neo-classical framework give scope to specific forms of transaction costs. Regulatory factors affect money circulation, savings, consumption, and financing in an economy by the intermediaries and agents navigating the twin aspects, solvency, and liquidity. It is evidenced that bank capital affects bank safety, the ability of bank to refinance, and the bank's ability to extract repayment from borrowers or its willingness to liquidate them. Hence, the legal-based view sees regulation as a crucial factor that affects the efficiency of financial intermediaries. However, it is significant for an economy to have efficient financial intermediaries in order to overcome three crucial issues such as information asymmetry in the market, reducing the transaction costs and enabling financial regulation to work smoothly.

Intermediation costs in financial sector of an economy can be considered to be one of the indicators of efficiency of financial development. The deregulation of the banking systems and the entry of several private and foreign banks in some of the emerging economies have gradually induced greater competition, prompting banks to alter their business strategy and management practices which, along with technological developments, have led to overall improvement in efficiency. This was reflected in the intermediation cost (operating expenses as percentage of total assets) decelerating from 2.77 per cent in 1996 to 2.11 in 2006 in India. Notwithstanding this improvement, intermediation cost of banks in India is still high in comparison with other countries. There is, thus, scope to bring it down to the level of intermediation cost of banks in other Asian countries (see Figure 2).

Financial deepening has been shown to 'cause' growth (Demirgüç-Kunt and Maksimovic 1998; Rajan and Zingales 1998; Beck, Levine, and Loayza 2000; Levine, 2005). A doubling of private sector credits to GDP ratio is associated with a 2 percentage points increase in the rate of GDP growth. 


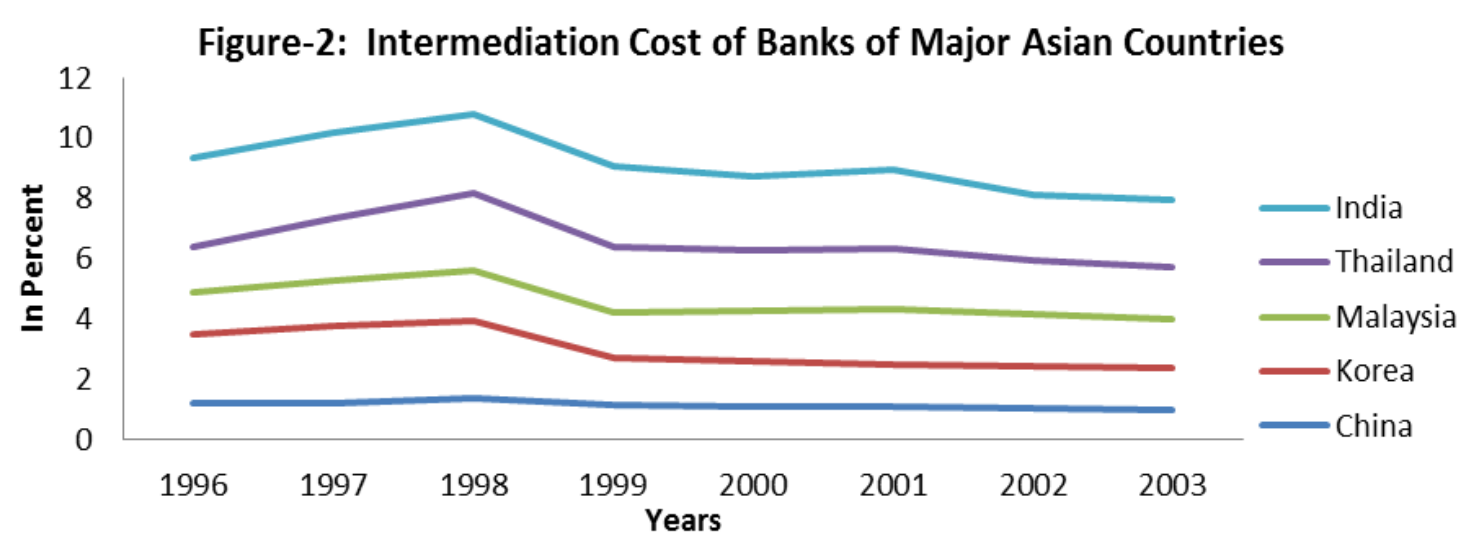

* Intermediation cost represents operating expenses as percentage to total assets.

Source: Developed by the author based on the data obtained from the following sources. 1. Mohan (2006c).

2. Report on Trend and Progress of Banking in India, various issues, Reserve Bank of India.

3. Report on Currency and Finance in India, (Credit Market in India), Reserve Bank of India.

Economies with higher levels of financial development experience faster reduction of poverty. Levine $(1998,1999)$ and Beck, Demirguc-Kunt and Levine (2007) have noticed a positive effect of finance on poverty reduction. This has been further explained by an extensive body of literature that includes Deininger and Squire (1998), Dollar and Kraay (2002), White and Anderson (2001), Ravallion (2001) and Bourguignon (2003). Financial depth, defined as the ratio of financial aggregates to GDP, appear to promote economic growth in only low-income developing countries while it has no effect in high-income countries (see Figure 3).

Figure-3a: Domestic credit provided by banking sector (\% of GDP) in OECD countries

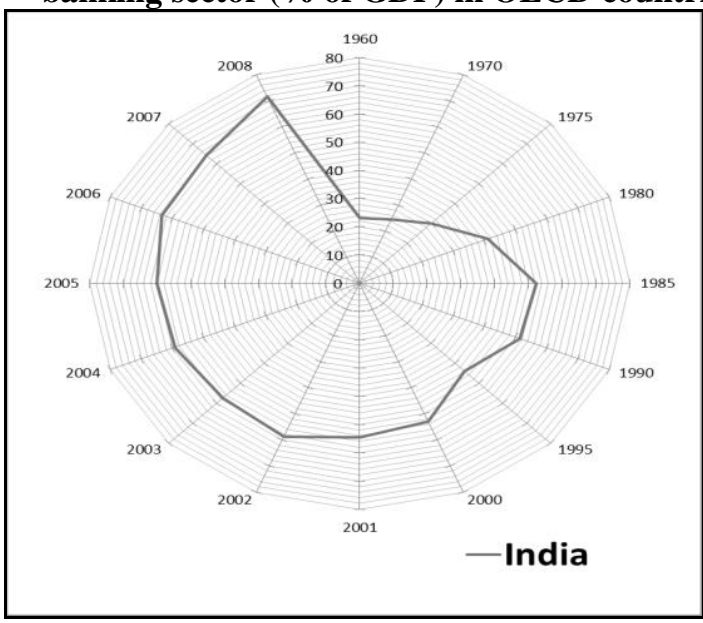

Source: World Bank Data
Figure-3b: Domestic credit provided by banking sector (\% of GDP) in India

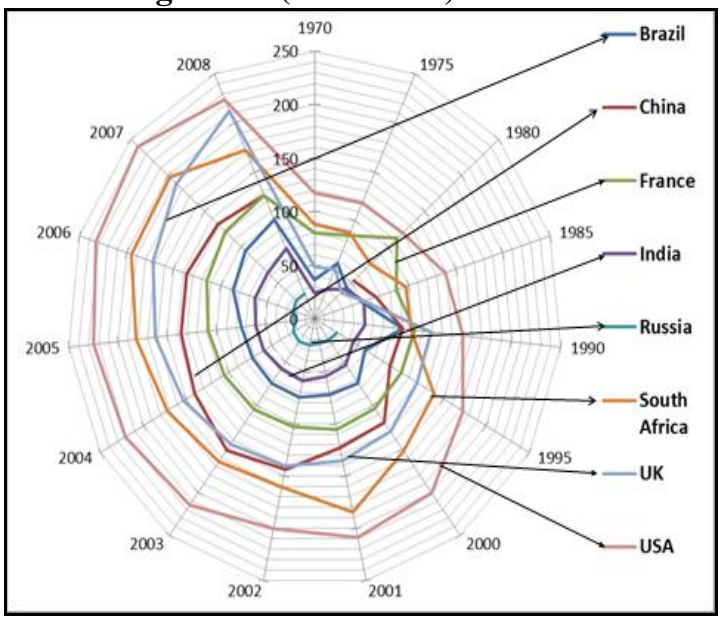

Source: World Bank Data

In order to achieve financial deepening there is a dire need to strengthen rural financial markets. In the desired process, undoubtedly, there is the necessity to sustain efficient financial intermediaries. 


\section{Economic Significance of Transaction Cost}

In economics and related disciplines, a transaction cost is a cost incurred in making an economic exchange. When rationally evaluating a potential transaction, it is important not to neglect transaction costs that might prove to be significant. Transaction cost theorists assert that the total cost incurred by a firm could be grouped largely into two components-transaction costs and production costs. Transaction costs, often known as coordination costs, are well defined as the costs of all the information processing necessary to coordinate the work of people and machines that perform the primary processes, whereas production costs include the costs incurred from the physical or other primary processes necessary to create and distribute the goods or services being produced.

Arguably, transaction cost reasoning became most widely known through Oliver E. Williamson's 'Transaction Cost Economics'. Today, transaction cost economics explain a number of different behaviors. Often, this involves considering as transactions not only as the obvious cases of buying and selling, but also of day-to-day emotional interactions, informal gift exchanges, etc. Transaction costs have been broadly defined by Steven (1992) as "any costs that are not conceivable in a Robinson Crusoe economy".

Given the critical role of credit markets in economic development, microfinance is being seen as one of the effective approaches for achieving financial development that eradicates poverty. Microfinance helps in three dimensions in attaining economic growth promoting economic opportunity, facilitating empowerment, and enhancing security. Transaction costs derive a lot of significance in the field of microfinance in view of the very nature of its provision of finance covering the space and distance of the targeted resource poor. It is an important cost factor involving the time and expenses for the beneficiaries. High transaction cost in rural credit system is one of the core problems that set back the viability of rural banking system. Microfinance is affected by transaction cost. Many of the credit instruments introduced in microfinance via the banks have not met with success because of the high transaction costs in rural credit delivery via the banks.

Self Help Groups (SHGs) that have emerged as suppliers of microfinance reduce transaction costs of financial institutions that do business with the poor and that of the SHGs themselves. They reduce the cost to financial institutions by acting as intermediary organizations 
or by providing social collateral that substitutes for costly loan appraisals and supervisions (Ajay, 2005). Llanto and Chua (1996) studied the transaction costs of two Philippines-based nongovernment organisations (NGOs). They concluded that there is an inverse relationship between an organisation's transaction costs and its number of years in existence. Motivation and retention of NGO staff were critical for transaction costs. Gonzalez-Vega et al., (1997) studied the transformation of BancoSol from an NGO MFI (Microfinance Institution) to a licensed commercial bank. The ratio of total costs to average number of loans outstanding increased from US\$ 149 (1992) to US\$ 242 (1994). Most of this increase came from higher cost of funds, but the ratio of operational costs to the average number of loans also increased from US\$ 103 to US\$ 135. One reason was the transformation was accompanied by an increase in the number of branches from 4 to 32 . The increased investment in infrastructure, monitoring and communication systems, and additional staff did not immediately generate sufficient number of loans. BancoSol compensated by increasing the revenue generating capacity of each loan by increasing loan sizes and increasing maturities. These studies have thrown much of the light on the transaction costs from the point of view of lending Non-Government Organisations.

In their study of the microcredit of the nationalized commercial banks in India, Puhazhendi (1995), Girija, and Satish (2000) concluded that non-governmental organizations (NGOs) and self-help groups (SHGs) in the credit delivery system reduced transaction costs of both banks and borrowers. Ajay (2002) identified the factors that influenced group formation costs. The most important factors identified were: the number of groups handled by a field worker and his/her conveyance expenses; group training costs; and average staff salaries in the region. Karduck and Siebel (2004) studied transaction costs of borrowers and concluded that weekly as against monthly meeting schedules increase transaction costs by 34 per cent in all places in their Indian study. These studies have underscored the importance of reduction in transaction costs for the lending organisations.

The SHGs are projected as potential micro-banks, either on their own or through higher levels of association, capable of using their own resources, grants, and borrowed funds for financial intermediation. Within this role for SHGs, models and approaches have emerged, representing different methods of ensuring effectiveness and sustainability. These models envisage solely financial intermediation or include other non-financial elements as well. Given the diversity of approaches being practiced in financing the poor, it is desirable to examine the borrowing costs for the poor. Much of the literature available on transaction costs in 
microfinance deals with lender's perspective mostly ignoring the borrower's perspective. The author is of the opinion that it is the transaction costs of borrowing for the poor that is important which needs to be reduced in order to motivate and induce the poor to avail these services instead of focusing only on the transaction costs for the lender even though it too is equally important. This study brings the required focus on the transaction costs of borrowing by the poor, and makes an empirical analysis of the same apart from providing required insights for policy support that is needed to lessen the burden on the microfinance beneficiaries.

The principal objective of this study is to bring more focus on the aspects of transaction costs in borrowing for the poor while the poor avail finance form the institutional and informal sources. Transaction costs in borrowing for the poor should be studied from the borrower's point of view. Accordingly, the objectives of this study are:

- To estimate the transaction costs of borrowing for the poor in both the prominent models of lending to the poor that are prevailing in India;

○ Under Direct Lending method from the Institutional sources; and

- Under the Self Help Group Linkage approach;

- To compare the transaction costs of borrowing for the poor in the above said two methods of lending for the poor; and

- To suggest measures to bring down the transaction costs of borrowing for the poor in order to help the borrowing poor and to expand the reach of rural finance.

\section{Methodology and Research Design}

The study sets out to understand the importance of transaction costs of borrowing for the poor and estimate them in different models lending to the poor. In addition, this study attempts answer the question like: (1) what are these costs for a borrowing poor. (2) how significant are these for the poor in making a decision for borrowing from institutional source or informal source? The study has drawn extensively on recent literature on SHGs and microfinance in ascertaining the different dimensions of transaction costs SHG bank linkage program and other methods of lending in the SHG movement. Reserve Bank of India in 1991, issued a directive to all scheduled commercial banks encouraging them to establish linkages directly with NGOs and SHGs in 
India, using the latter as financial intermediaries of the banks to reach the poor. Subsequently guidelines were issued by National Bank for Agriculture and Rural Development (NABARD) for a pilot project to link banks with SHGs.

The SHG promotion movement has gathered momentum since 1998 and there has been phenomenal rise in the number of SHGs due to the active support of banks, government organizations and non-government organizations. For the purpose of study, we consider a tenyear period upto 2008 as a suitable period for the study. Accordingly, March 2008 has been chosen as the reference period as the study was commenced during this period.

In India, southern region has dominated the SHG-bank linkage programs since the launch of the pilot project to link SHGs with banks. In terms of cumulative number of SHGs linked with banks, Karnataka has been among the top three, the other are Tamil Nadu and Andhra Pradesh. In Karnataka state, Shimoga has led the way in the formation and linkage of SHGs with banks. The district provides an ideal region to undertake the study in view of the diverse culture, climate encompassing the maidan region (temperate plain region) and malnad region (hilly forest region) consisting of Thirthahalli, Sagara and Hosanagara blocks endowed with majestic Sahyadri hill ranges and thick forest cover.

Some of the salient features of the district which prompted us to select this district as study area are; Shimoga district has the distinction of having 2755 SHGs linked to the banks under linkage programme with cumulative bank loan disbursed upto INR 839.1 million [US $\$ 18.24$ million] by March 2008 (reference period). The district provides an ideal region to undertake the study in view of the diverse culture, climate, and people. The district has a good mix of quite old and new SHGs ranging from 12 years to 1 year old. About 15 to 20 nongovernment organizations (NGOs) are actively engaged in SHG formation and linkage programs apart from the active participation by local bank branches and the state government's women empowerment departments. Therefore, Shimoga district was selected as a region since all the indicators are very well stabilized.

The authors have brought a field perspective to the study. It is based on primary data which are collected by participating in several meetings of the SHGs, interviewing the SHG members and microfinance practitioners in the study area. Field interviews with SHG members, SHG federations office bearers, other villagers and microfinance practitioners were jotted down and were subsequently detailed out using MS Office Excel sheet in order to make the data 
unambiguous to arrive at correct estimates of the costs of the different components involved in the borrowing by the poor. Informal interviews to allow others to interact freely and share information - including SHG federation office bearers, group members, and neighbors - was encouraged in order to gain a broader perspective on the topic. Elite interviews with the branch manager of lending banks in the area were conducted to gain the lenders perspectives.

Data related to 'opportunity cost of one man day lost in availing finance' and the 'cost of documentation' in connection with the availment of loan by the poor are collected using the stratified random sampling method covering all the seven blocks in the district. Transaction costs of borrowing for the poor per loan account were estimated based using data collected from 700 survey questionnaires/interview data involving 100 each for all the seven blocks of Shimoga district in the state of Karnataka in India.

Transaction costs of borrowing for the poor were estimated using the cost-allocation method. Estimates of time spent by borrower for the identified functions or tasks were used to calculate the cost of borrowing for an average loan amount of INR 10,000.00 (US\$215.00) per account.

\section{Empirical Analysis}

When the borrower is required to avail credit from any source of finance, he/she incurs some costs that are other than the interest costs, service charges, and other loan related charges levied by the finance provider. Such costs are normally incurred by the borrower for his own needs during the process of securing a loan. These costs normally include, cost of visits to bank branch, cost of document collection, cost of loan applying, cost of loan availment, cost of visit to bank branch by office bearers of the SHG and other such activities. We compute and analyse the transaction costs incurred by the poor in securing loans in two broad models: (i) Direct loans to individuals by banks model and (ii) SHG-Bank linkage model. The quantum of loan amount involved in the assessment is presumed for the poor as about (INR) Rs10,000.00. ${ }^{1}$

Direct Lending by Banks Model: This is a traditional model of loan availment by the poor since decades of directed lending by the formal financial institutions in India. Under this model, the poor approach the bank branch for loans for their various purposes. The borrower incurs

\footnotetext{
${ }^{1}$ Transaction costs are estimated in Indian Rupee (INR) represented as INR or Rupee symbol.
} 
transaction costs for loan availment apart from other costs such as interest costs, service charges and other charges levied by the banks.

Table 1: Transaction costs of borrowing by the poor, direct lending by banks

\begin{tabular}{|c|c|c|c|}
\hline Sl. No. & Type of Activity & $\begin{array}{l}\text { Money Cost } \\
\text { in INR }\end{array}$ & $\begin{array}{l}\text { Total Cost } \\
\text { in INR }\end{array}$ \\
\hline 1. & \multicolumn{2}{|l|}{ Cost of initial visit to bank branch } & 100 \\
\hline 1 & Opportunity cost of one day wages & 60 & \\
\hline 2 & Transportation cost of the visit & 20 & \\
\hline 3 & Incidental cost of the visit & 20 & \\
\hline & \multicolumn{2}{|l|}{ Cost of second visit to bank branch } & 225 \\
\hline 1 & Opportunity cost of one day wages & 60 & \\
\hline 2 & Transportation cost of the visit & 20 & \\
\hline 3 & Incidental cost of the visit & 20 & \\
\hline 4 & $\begin{array}{l}\text { Cost of account opening: cost of photos = Rs. } 15 \\
\text { Cost of duplication of address proof = Rs. } 5 \\
\text { Transportation cost involved = Rs. } 25 \\
\text { Opportunity cost of time spent [one day] = Rs. } 60 \\
\text { Incidental costs[refreshments] = Rs. } 20\end{array}$ & 125 & \\
\hline 3. & \multicolumn{2}{|l|}{ Cost of document collection } & 150 \\
\hline 1 & Opportunity cost of one day wages & 60 & \\
\hline 2 & Transportation cost of the visit & 20 & \\
\hline 3 & Incidental cost of the visit & 20 & \\
\hline 4 & Cost of document collection & 50 & \\
\hline & \multicolumn{2}{|l|}{ Cost of loan applying } & 120 \\
\hline 1 & Opportunity cost of one day wages & 60 & \\
\hline 2 & Transportation cost of the visit & 20 & \\
\hline 3 & Incidental costs of the visit & 20 & \\
\hline 4 & Related expenses & 20 & \\
\hline \multicolumn{3}{|c|}{ 5. Cost of loan availment } & 325 \\
\hline 1 & Opportunity cost of one day wages & 60 & \\
\hline 2 & Transportation cost of the visit & 20 & \\
\hline 3 & Incidental cost of the visit & 20 & \\
\hline 4 & $\begin{array}{l}\text { Procurement cost of stamp paper and revenue stamps: } \\
\text { Cost of stamp paper = Rs. 50 } \\
\text { Cost of revenue stamps = Rs.5, cost of photos = Rs. } 10 \\
\text { Opportunity cost of time spent [one day] = Rs. } 60 \\
\text { Transportation cost involved = Rs. } 25 \\
\text { Incidental costs[refreshments] = Rs. } 20\end{array}$ & 175 & \\
\hline \multirow[t]{2}{*}{5.} & $\begin{array}{l}\text { Service charges for loan[ for an average loan of Rs. } 10000 \\
\text { @ Rs.5 per thousand }\end{array}$ & 50 & \\
\hline & Total & & 920 \\
\hline
\end{tabular}

The various components of transaction costs of borrowing for the poor under the traditional model of direct loans to individuals are fragmented and arranged here according to their order of occurrence. 
Costs involved are: (1) cost of initial visit to bank branch, (2) cost of second visit to bank branch, (3) cost of document collection, (4) cost of loan applying and (5) cost of loan availment. After having estimated the various components of transaction costs involved in borrowing for the poor from the bank under model: Direct loans to individuals, the total transaction cost involved is derived as mentioned below.

Further, we present here below (Table 2) the proportion of above detailed activities in the transaction costs of borrowing by the poor under the direct lending by banks model.

Table 2: Transaction costs of borrowing by the poor under direct lending by banks - Activity wise distribution of costs

\begin{tabular}{|c|l|c|c|}
\hline S1. No & \multicolumn{1}{|c|}{ Type of Activity } & $\begin{array}{c}\text { Amount } \\
\text { in INR }\end{array}$ & $\begin{array}{c}\text { Percentage to } \\
\text { Total Cost }\end{array}$ \\
\hline 1 & Cost of initial visit to bank branch & 100 & $11 \%$ \\
\hline 2 & Cost of second visit to bank branch & 225 & $24 \%$ \\
\hline 3 & Cost of document collection & 150 & $16 \%$ \\
\hline 4 & Cost of loan applying & 120 & $13 \%$ \\
\hline 5 & Cost of loan availment & 325 & $36 \%$ \\
\hline & Total & 920 & $100 \%$ \\
\hline
\end{tabular}

It is noticed that a significant proportion of transaction costs is involved in visiting the bank branch (i.e 35\%) and document collection (16\%) and loan applying (13\%).

\subsection{Transaction Cost of Borrowing for the Poor under SHG-Bank Linkage Model}

After the emergence of SHGs as the financial intermediaries for the poor under microfinance, the poor are grouped into SHGs and in turn linked with banks for availing loans as explained earlier in this study. Under this model, the poor members of the group approach the group for loans for their various purposes during their regular meetings. The group's borrowing member incurs transaction costs for loan availment in addition to other costs such as interest costs, and other charges levied by the banks. Here in this assessment, the service charges of 1 per cent of the loan amount levied by the group on the borrowing members are considered as a component of transaction cost. It is believed that the member of the group does not incur any additional transaction cost apart from what the group has incurred during the linkage process.

The various components of transaction costs of borrowing by the poor under the traditional model of direct loans to individuals are fragmented and arranged here below according to their order of occurrence. Costs involved are: (1) cost of initial visit to bank branch 
(by 3 office bearers of the SHG), (2) cost of second visit to bank branch for submission of loan application and (3) cost of loan availment.

Table 3: Costs of borrowing by the poor from the bank under SHGs

\begin{tabular}{|c|c|c|c|}
\hline Sl. No. & Type of Activity & $\begin{array}{c}\text { Money Cost } \\
\text { in INR }\end{array}$ & $\begin{array}{c}\text { Total Cost } \\
\text { in INR }\end{array}$ \\
\hline 1. & \multicolumn{2}{|l|}{ Cost of initial visit to bank branch } & 270 \\
\hline 1 & Opportunity cost of one day wages[3x Rs.60] & 180 & \\
\hline 2 & Transportation cost of the visit[3x Rs.20] & 60 & \\
\hline 3 & Incidental cost of the visit & 30 & \\
\hline 2. & \multicolumn{2}{|l|}{ Cost of second visit to bank branch for submission of loan application } & 275 \\
\hline 1 & Cost of preparation of resolution and loan project report & 5 & \\
\hline 2 & Opportunity cost of one day wages[3x Rs.60] & 180 & \\
\hline 3 & Transportation cost of the visit[3x Rs.20] & 60 & \\
\hline 4 & Incidental cost of the visit & 30 & \\
\hline 3. & \multicolumn{2}{|l|}{ Cost of loan availment } & 1690 \\
\hline 1 & Opportunity cost of one day wages[3x Rs.60] & 180 & \\
\hline 2 & Transportation cost of the visit[3x Rs.60] & 60 & \\
\hline 3 & Incidental cost of the visit & 30 & \\
\hline 4 & $\begin{array}{l}\text { Procurement cost of stamp paper and revenue stamps: } \\
\text { Cost of stamp paper = Rs.100 } \\
\text { Cost of revenue stamps = Rs.5, cost of photos = Rs. } 45 \\
\text { Opportunity cost of time spent [one day x 3] = Rs.60x3= Rs. } 180 \\
\text { Transportation cost involved[3x Rs.20] = Rs.60 } \\
\text { Incidental costs = Rs. } 30\end{array}$ & 420 & \\
\hline \multirow[t]{3}{*}{5.} & $\begin{array}{l}\text { Service charges for loan[ for an average loan of Rs.100000] } \\
\text { i.e @ Rs.1 per Rs. } 100\end{array}$ & 1000 & \\
\hline & Total & & 2235 \\
\hline & Then, per member transaction cost== Rs. $2235 / 10$ & & 224 \\
\hline
\end{tabular}

Further, we present here below (Table 4) the proportion of above detailed activities in the transaction costs of borrowing by the poor under SHG-Bank Linkage Model. Figure 4 presents the comparison of activity-wise costs of transaction under both models as a comparison.

Table 4: Costs of borrowing for the poor from the bank under SHG-Bank Linkage Model - Activity wise distribution of costs

\begin{tabular}{|c|l|c|c|}
\hline Sl. No. & \multicolumn{1}{|c|}{ Type of Activity } & $\begin{array}{c}\text { Amount } \\
\text { in INR }\end{array}$ & $\begin{array}{c}\text { Percentage to } \\
\text { Total Cost }\end{array}$ \\
\hline 1 & Cost of initial visit to bank branch & 270 & $12 \%$ \\
\hline 2 & $\begin{array}{l}\text { Cost of second visit to bank branch for submission of loan } \\
\text { application }\end{array}$ & 275 & $12 \%$ \\
\hline 3 & Cost of loan availment & 1690 & $76 \%$ \\
\hline & Total & 2235 & $100 \%$ \\
\hline
\end{tabular}


Figure 4: Comparison of transaction costs of borrowing

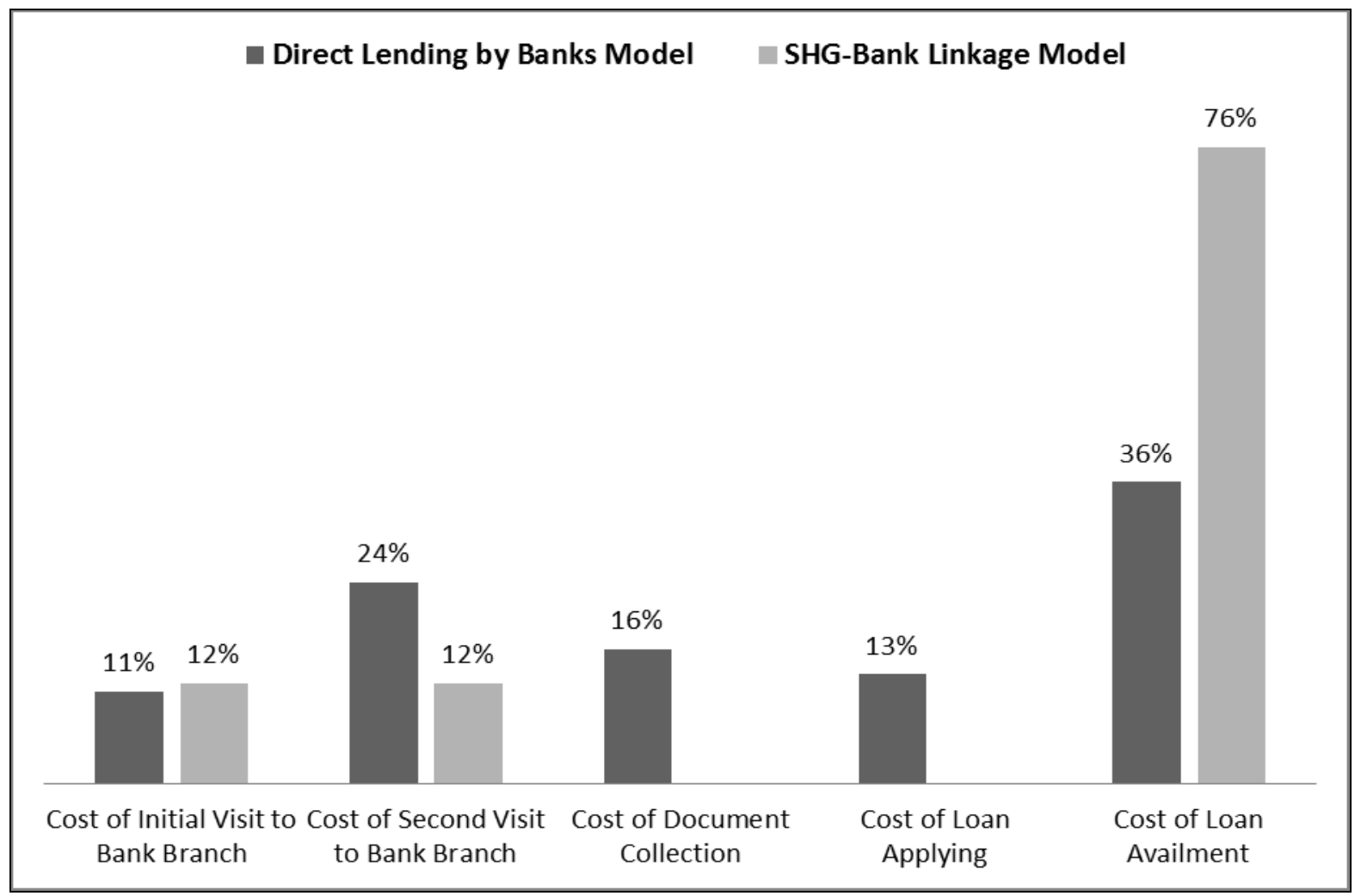

Note: Percentage of different sub costs to total transaction costs in models of comparison

Figure 5: Comparison of transaction cost for borrower under direct loan model and SHG-Bank Linkage Model

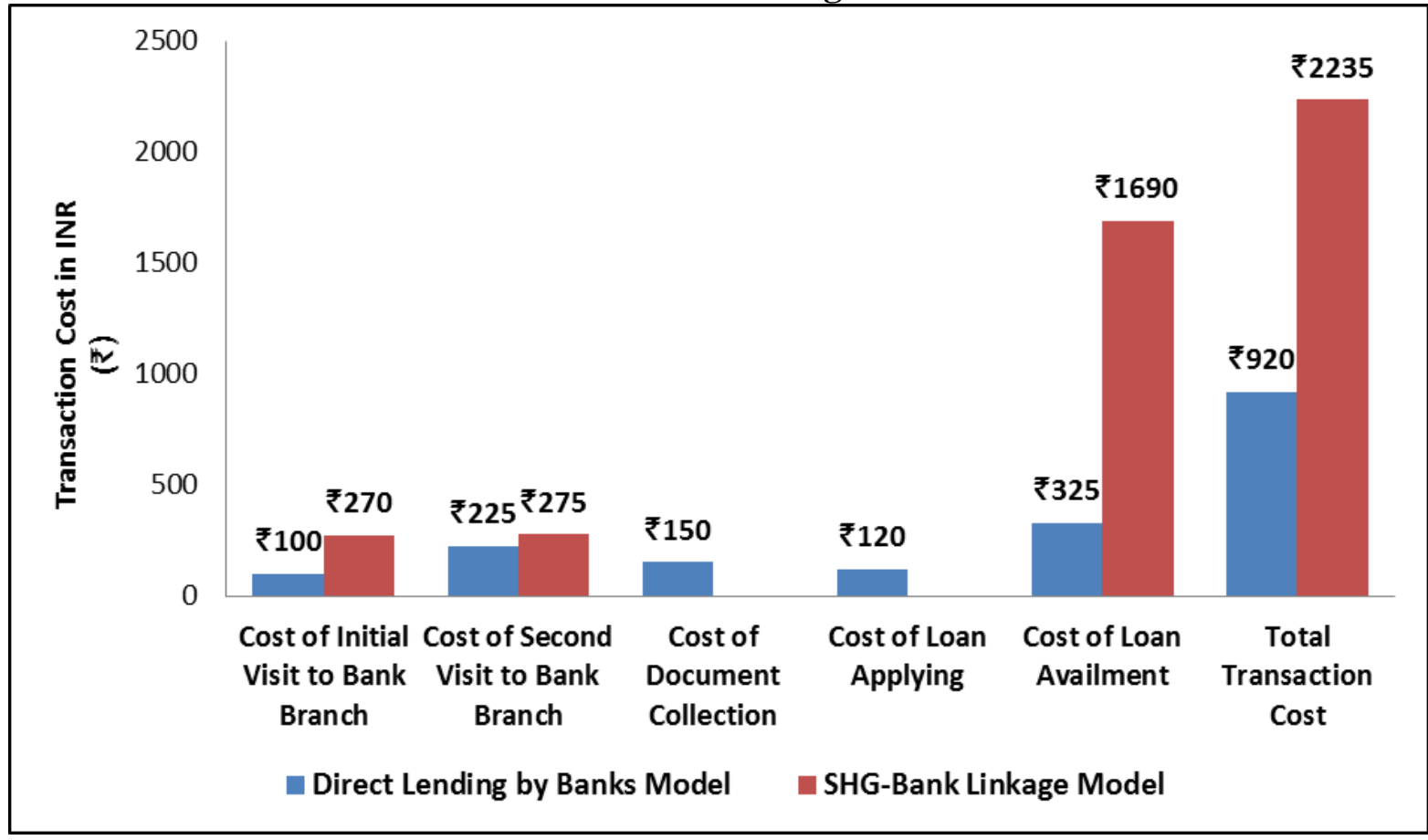

Note: Transaction costs in models of comparison represented in Indian Rupee (INR) 
As is evident from these statistics of the survey results, direct lending by banks incurs the most transaction costs. Obviously, Linkage Model attracts lower number of activities, hence lower the costs.

Figure 5 presents the comparison of transaction costs of borrowing along with activity wise costs under the models studied for comparison. The total cost of linkage model is INR 2,235 against the INR 1,840 for the direct lending model. Obviously direct lending attracts less transaction costs.

On a comparison, we notice that microfinance through SHGs offers significant disadvantages in terms of transaction costs for borrowers when compared to the traditional direct loan model followed by banks (see figures 4 and 5).

\section{Findings, Limitations, Policy Choices and Conclusion}

SHG-Bank Linkage is advantageous for the poor as the transaction cost of borrowing amounts to INR 224 per individual (Table-2) as against that of INR 920 (Table-1) under the Direct Lending by Banks Model. SHG loan model's transaction cost of borrowing for the poor is about one fourth the transaction cost under Direct Lending by Banks Model. In view of this, it is beneficial to encourage financial provisions for the poor under the SHG Model in order to cut down the transaction costs for the poor. It is established by the study that transaction costs for the borrowing poor significantly decrease when they use the SHG-bank linkage models of microfinance. It is important to ascribe due importance towards reduction of these costs in order to help the borrowing poor thereby inducing them to embrace microfinance to achieve economic development. The significant reduction in transaction costs of borrowing offers stimuli to all the prospective borrowers to show interest in the SHG programs that is emerging as a microfinance tool for the benefit of the resource poor. SHGs offer a significant reduction in such costs of transaction that makes another selling point for the SHGs.

Generalisations based on the case studies should be done with caution. In view of the difficulty in covering all the areas of the country in sampling, the study area keeping in view of the prominent visibility of the microfinance activity in the area and also the awareness level of the beneficiaries. Further, specific studies on transaction costs of borrowing by the poor at the national and global levels involving larger sample would be useful. 
The policy of supporting SHG linkages with banks has merit in a country with a large bank network and as vast in space as India. However, additional efforts are needed to create and nurture competitive MFIs willing to penetrate into the remote areas of country. Banks should encourage SHG-Bank Linkage since transaction costs of borrowing are significantly lower compared to transaction costs under banks' direct lending to individuals. Some of the measures that can be taken to reduce the transaction costs are (a) simplifying the documentation process and (b) arranging provision of credit at doorsteps of the poor as far as possible. The local governments can consider utilizing the services of the line department personnel who are in close contacts with the poor to form SHGs in order to bring down the transaction costs both for the lenders as well as for the borrowers. Banks need to simplify their systems and procedures without compromising on the legalities involved to bring down the costs of transaction for borrowers too. The governments both at the centre and at the state can consider the possibilities of implementing the entire subsidy/margin oriented schemes through the SHGs so that recovery performance and end utilization can be ensured along with reduction in the transaction costs of borrowing for the poor.

This study has established that effective financial intermediation leads to financial development. To achieve financial development on a sustainable basis, it is important to reduce the transaction costs of not only the lenders but also that of the borrowers. This could be ensured by designing appropriate cost efficient financial intermediaries, which may significantly reduce the transaction costs. Innovation in financial intermediation such as the microfinance models can surely spur the rate of financial development, which in turn can lead to economic growth.

Author information: The submitting author is a professor at the Indian School of BusinessHyderabad, India. He may be contacted at vighneswar@ibsindia.org. His co-author B.K. Tulasimala is from University of Mysore, India.

\section{REFERENCES:}

Beck, T., Levine, R., and Loayza, N, (2000). Finance and the sources of growth. Journal of Financial Economics, 58: 261-300.

Beck, T., Demirgüç-Kunt, A., and Levine, R., (2007). Finance, inequality and the poor. Journal of Economic Growth, 12(1): 27-49

Bourguignon, F., (2003). The growth elasticity of poverty reduction; explaining heterogeneity across countries and time periods, in Inequality and growth: Theory and policy implications, ed. T. Eicher and S. Turnovsky, Cambridge, MA: MIT Press. 
Steven, Cheung, N. S., (1992). On the new institutional economics in L.Werin and H. Wijkander (eds.), Contract economics, Basil Blackwell Publishers 1992: 48-65

Deininger, K., and Squire, L., (1998). New perspectives on old issues: Inequality and growth. Journal of Development Economics, 57(2): 259-288.

Demirgüç-Kunt, A., and Maksimovic, V., (1998). Law, finance, and firm growth. Journal of Finance, 53: 2107-2137

Dollar, D., and Kraay, A., (2002). Growth is good for the poor. Journal of Economic Growth, 7: $195-25$

Gonzalez-Vega Claudio, Schreiner Mark, Meyer Richard L., Rodriguez Jorge and Navajas Sergio, (1997). BancoSol: the challenge of growth for micro finance organisations, OECD Publication

Karduck Stefan and Siebel Hans Dieter, (2004). Transaction costs of self-help groups in NABARD's SHG banking program: a study in Karnataka state. NABARD, India

Levine, R, (1997). Financial development and economic growth: views and agenda. Journal of Economic Literature, 35: 688-726.

Levine, R, (1998). The legal environment, banks, and long-run economic growth. Journal of Money, Credit and Banking, 30: 596-613.

Levine, R, (1999). Law, finance, and economic growth. Journal of Financial Intermediation, 8: $36-67$

Llanto Gilberto, M, and Chua Ronald T, (1996). Transaction costs of lending to the poor: A case study of two Philippine non-governmental organizations. www.bwtp.com

Nair, Ajai, (2005). Sustainability of microfinance self-help groups in India: would federating help? Policy Research Working Paper Series, World Bank

Patrick, H., (1966). Financial development and economic growth in underdeveloped countries. Economic Development Cultural Change, 14: 174-189.

Puhazhendi, V., (1995). Transaction costs of lending to the rural poor: non-governmental organizations and self-help groups of the poor as intermediaries for banks in India" (www.bwtp.com)

Rajan, Raghuram, Zingales G. Luigi, (1998). Financial dependence and growth. American Economic Review, 88 (3): 559-586

Ravallion, M., (2001). Growth, inequality and poverty: looking beyond averages, World Development, 29(11): 1803-1815

Sen, Amartya, (2000). Development as freedom, Anchor Books, New York 
Srinivasan Girija and Satish, P., (2000). Transaction costs of SHG lending - impact on branch viability. Banker's Institute of Rural Development, Lucknow, India

Tankha, Ajay, (2002). Self-help groups as financial intermediaries in India: cost of promotion, sustainability and impact, Sa-Dhan, India

White, H., and Anderson, E., (2001). Growth vs. redistribution: does the pattern of growth matter? Development Policy Review, 19(3): 167-289. 